\title{
Elusive drusen and changing terminology of AMD
}

\author{
P. T. V. M. De Jong ${ }^{1,2,3}$
}

Received: 4 October 2017 / Accepted: 3 November 2017 / Published online: 9 February 2018

(c) The Author(s) 2018. This article is published with open access

\begin{abstract}
The first descriptions of ageing macula disorder (AMD), be it under other names, appeared in 1855 and 1868 . The earliest accounts of AMD linked the presence of drusen with visual loss. It took a century before these connections between drusen and AMD were generally accepted by medical science and in clinical articles. The first signs of AMD appear in the region of the choriocapillaris, Bruch's membrane and the retinal pigment epithelium. The pathogenesis of drusen and of AMD is still uncertain. This is reflected in the wide variation in nomenclature of both, since the first publications.
\end{abstract}

\section{Introduction}

Our knowledge of ageing macula disorder (AMD) has markedly increased over the last 50 years in tandem with a growing interest in this disorder, partly owing to its increased prevalence in populations with a higher life expectancy. Later in this review, an explanation is given as to why the term ageing macula disorder is preferred to agerelated macular degeneration (both similar, and abbreviated as AMD), a disorder that by definition occurs only in persons arbitrarily 50 years of age or older [1]. The first aim of this review is to examine, where possible, the earliest available descriptions of tissue changes that are at the present time considered to be associated with AMD, among others of drusen. There are reviews on the pathogenesis or treatment of AMD but these did not focus on changes in its nomenclature [2-4]. The first publications indicating AMD spring from 160 years ago. Changes in AMD terminology since the first publications will be discussed, revealing the uncertainty of researchers about the pathophysiology of AMD.

P. T. V. M. De Jong

p.dejong@nin.knaw.nl

1 Department of Retinal Signal Processing, The Netherlands Institute for Neuroscience, KNAW, Amsterdam, The Netherlands

2 Department of Ophthalmology, Academic Medical Center, Amsterdam, The Netherlands

3 Department of Ophthalmology, Leiden University Medical Center, Leiden, The Netherlands

\section{Original descriptions of tissue changes associated with AMD from the outer to the inner eye}

\section{The choroid}

The choroid is customary divided into the large vessel layer of Haller, the smaller vessel layer of Sattler, and the choriocapillaris. Duke-Elder considered Bruch's membrane (BrM) to be part of the choroid [5]. With advancing age the choroid, including the choriocapillaris, becomes thinner in maculae with or without signs of AMD. In neonates its thickness is $0.15-0.3 \mathrm{~mm}$, in adults $0.1 \mathrm{~mm}$ [6]. In very old people the reduction in choroidal thickness is $57 \%$ compared with the youngest age group [7]. The choroid in AMD was reported to be either normal or have sclerotic vessels with atheromatous changes. The choriocapillaris was considered by some to be the primary affected tissue and in it lymphocytes were found near AMD lesions [2].

\section{Bruch's membrane (BrM)}

Carl Bruch described this membrane, which was named after him, in 1844 in his monograph on granular pigments in vertebrates [8]. BrM is an extracellular matrix between the choriocapillaris and the retinal pigment epithelium (RPE). Bruch wrote that Eschricht described six years earlier this membrane in the seal [8]. Thus BrM should have been called Eschricht's membrane [9]. Early researchers noticed that BrM becomes thicker around age 70 years [10]. It thickens over time by $135 \%$ whether signs of AMD are present or not [7]. Histologically, half of 13 eyes 
a

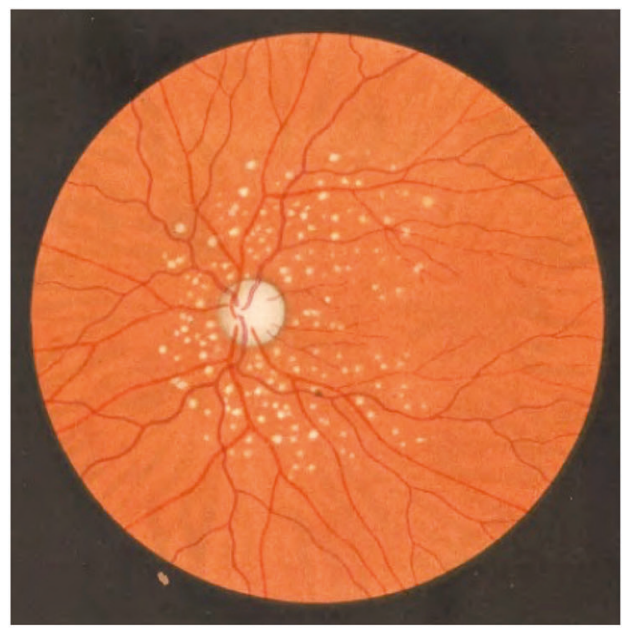

b

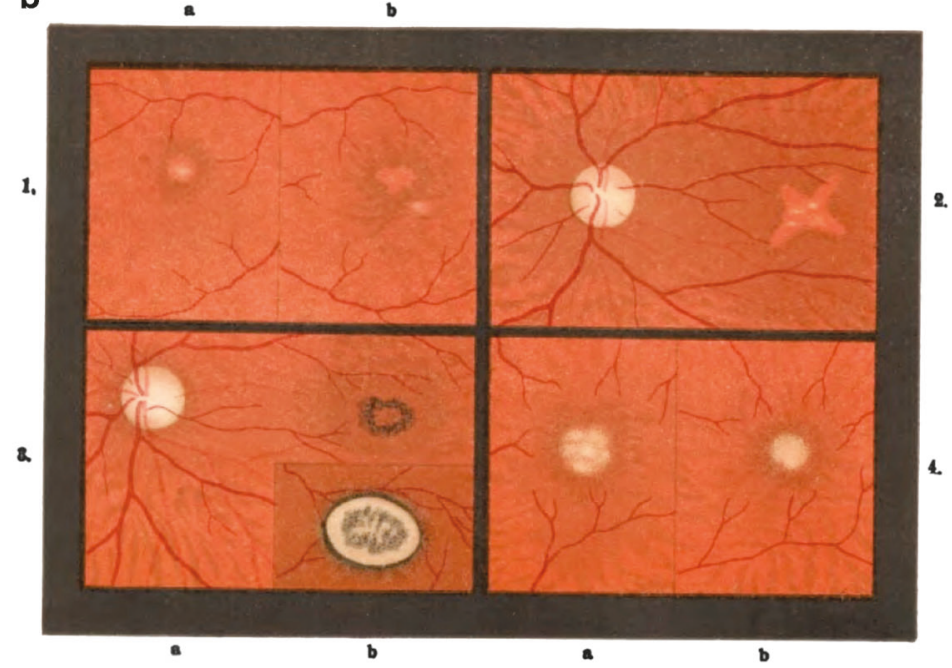

Fig. 1 (a) Drusen of the vitreous membrane of the choroid. Haab wrote: These drusen, also a change in old age, have nothing to do with the macular disorder depicted here and should be distinctly separated from this. [20] (b) Images of senile macular disease. [20] 1. a b Macula of right and left eye from a 70-year-old person; 2 . No legend given. 3. a Beginning signs of disease; 3. b 6 months later; 4. a b Right and left eye from a 74-year-old female with disciform macular degeneration (dMD) had ruptures in BrM which were crossed by new vessels [2]. So for $\sim 80$ years people knew that changes in BrM were associated with AMD. Only recently, three types of multilaminar sub-RPE hyper reflectivity were detected with optical coherence tomography in the inner, the outer, or both layers of $\mathrm{BrM}$, in eyes with regressing drusen [11].

\section{The retinal pigment epithelium (RPE)}

The retinal pigment epithelium was first described in 1791 [12, 13]. Bruch again elaborately described the RPE and was struck by its monolayer and regular, hexagonal shape [8]. He pointed out that the cones were standing directly on the RPE cells without any membrane or structure between them, and that they had a pigment sheath [8]. Frans Donders mentioned in 1855 RPE atrophy between groups of drusen [14]. It gradually became clear that the RPE could become hypertrophied and after fibrous metaplasia could contribute to fibrous tissue in disciform lesions [2, 3, 15, 16].

Basal laminar or basal linear deposits between the cell membrane and the basement membrane of the RPE, are often present before drusen appear. These terms were not used in the original electron microscopic descriptions of these deposits [17]. Don Gass called them 'eosinophilic material between an irregularly thickened BrM and overlying degenerated RPE' [16]. Shortly afterwards Shirley Sarks identified in 1970 three types of deposits [18] and it seems that she coined the term basal linear deposit [19].

\section{Drusen}

Drusen are small yellow-white deposits on BrM that press while enlarging through the RPE and thus become visible on ophthalmoscopy as white spots in the retina, both in the macular area as in the retinal periphery. Drusen are now considered to be a hallmark of AMD but this connection was explicitly denied by Haab who first described senile Macular Disease (MD) (Fig. 1) [20]. Around 1850, three authors, Wedl, Donders, and Müller, gave drusen different labels (Table 1). Carl Wedl named them colloid bodies of the choroid and thought they were incompletely developed cells, because they had no cell membrane or nucleus [21]. Donders called them colloid balls surrounded by pigment, noting their preference for the macular area. He used $\sim 10$ acids and lye's at various temperatures, even boiling them to determine their composition, thus being one of the first ophthalmic histochemists. He described the growth and confluence of the drusen and concluded that drusen originate from RPE cell nuclei [14]. Heinrich Müller mentioned deposits on the inner side of the choroid that had a ballshaped or drusenoid form. In this paper from 1856 he coined the word 'druse' (Table 1) [10]. Druse is the German word for geode, a cavity in rock filled with crystals, and Müller probably chose this name because of the crystalline core in some large drusen [22]. The first color image of drusen appeared in 1869 (Fig. 2) [23]. Over the years, several subtypes of drusen were discovered, one of the latest subdivisions being reticular, cuticular, or pseudodrusen [24]. Müller wrote that drusen originate behind the RPE and arise from focal thickenings in the structureless layer on the inner side of the choroid [10]. Later, the theory was 
Table 1 Various names for drusen

\begin{tabular}{llll}
\hline Year & Author & Original name & English translation \\
\hline 1854 & Wedl [21] & Colloidkörper von der Chorioidea & Colloid bodies of the choroid \\
1855 & Donders [14] & Colloidkugeln & Colloid balls \\
1856 & Müller [10] & kugelig-drusigen Körper; Druse & Ball-shaped, drusenoid bodies; druse \\
1868 & Nagel [40] & Krystalle; Krystalldrusen & Crystals; crystal drusen \\
1869 & Jäger von Jaxtthal [23] & Knotenförmige Exsudate in der Gefässhaut & Nodular exudates in the choroid \\
1874 & Hutchinson [36] & & 'Colloid' excrescences from the lamina elastica \\
1875 & Nagel [68] & Glashäutige Wucherungen & Proliferations of the glass membrane \\
1884 & Masselon [27] & Excroissances verruqueuses de la choroïde & Warty growths of the choroid \\
1896 & Oeller [70] & Verrucae laminae vitreae & Warts of the glass membrane \\
\hline
\end{tabular}

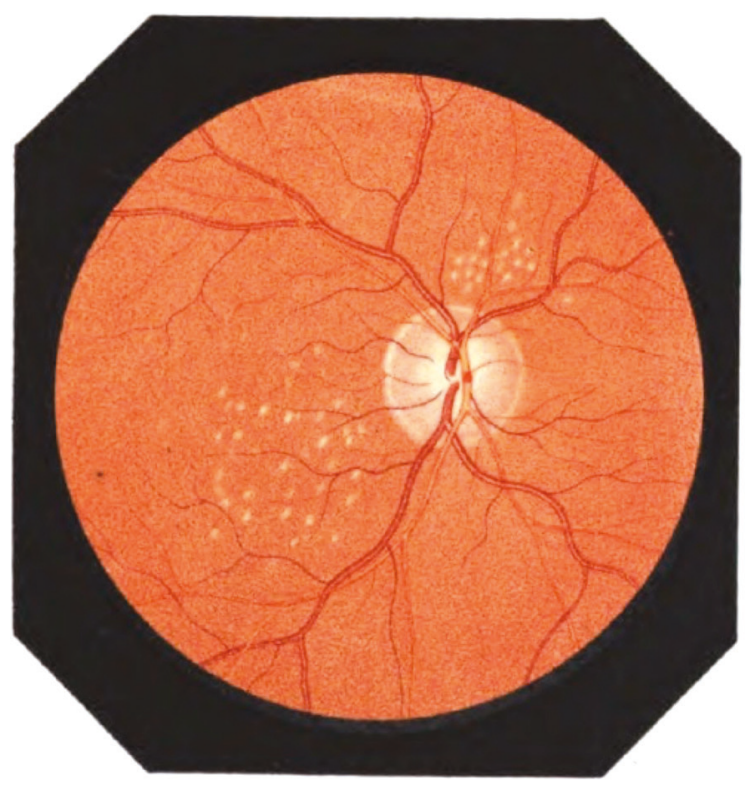

Fig. 2 First color image of drusen. These were called: Nodular exudates in the choroid. Table 1 [23]

formulated that drusen originate from leukocytes [25]. It is striking that 160 odd years on, we still do not know where exactly drusen originate from. The latest candidate again is the RPE, as Donders suggested [14, 26]. In 1884 drusen were even considered to be the cause of 'posterieur' glaucoma because drusen usually were located around the optic disc. This led to the assumption that thickening of the glasslike layer around the choroidal ring hampered the outflow of ocular fluid. This view was supported by the fact that drusen as well as glaucoma normally were present in both eyes of old persons (Fig. 3) [27].

\section{The retina}

The word retina was coined around 1150 AD by Gerardus Cremonensis in a mediaeval Latin translation of an Arabic text [28]. Felix Platter indicated in 1583 that the retina and not the lens was the light-sensitive organ in the eye [29]. Nearly 100 years later, a discoverer of the microscope, Antony van Leeuwenhoek, referred to 'clootgens' at the end of the fibers of the optic nerve spreading in the eye, that transmitted visible objects to the brain [30]. He used in Dutch the word 'clootgens' both to indicate cells and fat globules. The English translation of 'clootgens' as simply 'globules' may have blurred this distinction [30]. The photoreceptors were rediscovered 150 years later [31]. In 1839 Bidder depicted rods and cones in the chicken and mentioned that the rods were not oriented toward the light (the cornea) but towards the RPE [32]. Albert Kölliker was the first to describe the rods and cones in the human eye as two types of photoreceptors [33]. Only recently, new photosensitive ganglion cells were discovered in the retina, which drive the circadian clock via the suprachiasmatic nucleus [34].

In 1782, Francesco Buzzi described the retinal center, the macula lutea, after dissecting the eyes of a 35-year-old man [35]. The pathogenetic process underlying AMD is still not clear, nor the tissue primarily involved in it. It seems generally accepted that thickening of BrM and drusen formation in BrM and the RPE, as well as ruptures in BrM and RPE detachments leading to subretinal hemorrhages precede retinal changes of a secondary nature like photoreceptor loss or scarring $[2,36]$. It took nearly another 125 years since the paper by Verhoeff before angiogenic growth factors were discovered in AMD [37].

\section{Early reports on AMD}

As a lecturer in physiology, Donders hardly earned enough money to support his family. He agreed to translate Ruete's Textbook of Ophthalmology from German in Dutch while moonlighting, and thus became interested in ophthalmology. Two years after the invention of the ophthalmoscope [38] Donders' PhD student Adrien van Trigt wrote in 1853 a thesis on ophthalmoscopy in which the first world-wide color images of the fundus appeared (Fig. 4) [39]. In his early medical career Donders performed many autopsies. 
a

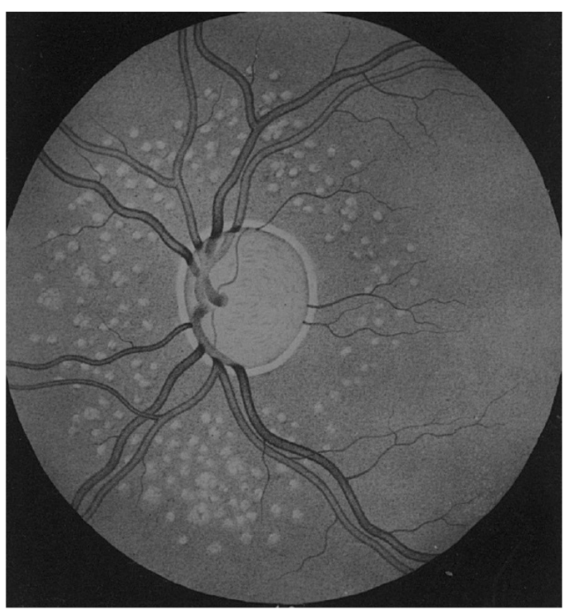

b

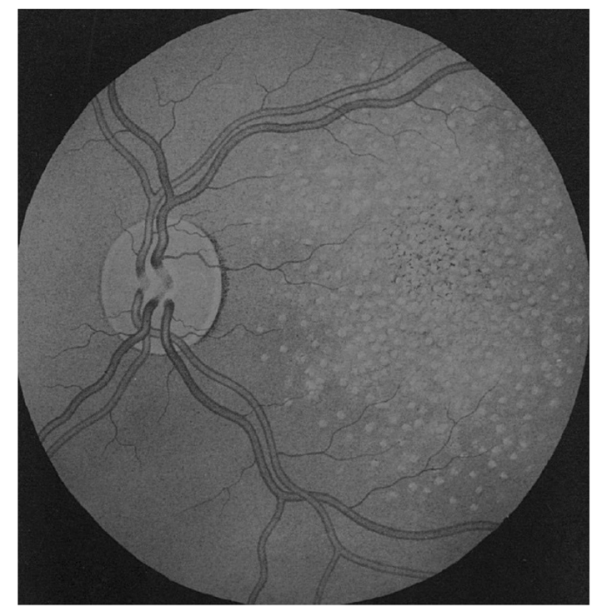

Fig. 3 (a) Inferred association between 'posterieur' glaucoma with total disc cupping and circumpapillary drusen. [27] (b) Drusen and pigmentary changes in the fundus



Fig. 4 First color images ever of the eye fundus [39] from thesis by Van Trigt [67]

From 1852 on, he realized the gap in understanding between what he saw using the ophthalmoscope and the microscope. So he started collecting 'healthy' post mortem eyes for histology. In 1855 after examining 38 apparently healthy eyes he wrote: 'An important question is in how far the degeneration described here (in the retina), can lead to visual disturbances' [14]. Using microscopy he noticed rods, obliquely oriented around small drusen as well as degeneration of the choriocapillaris and the RPE. On the choroidal side of the retina, rods and cones often were absent above drusen, that sometimes penetrated the retina halfway, without expanding the retina on the vitreous side. Drusen compressed the retina (Fig. 5) and rarely were absent in the eyes of persons aged 70-80 years. In none of the eyes that Donders examined post mortem, had the visual acuity been carefully recorded before death. However, Donders considered that the anatomical relation of the drusen to the retina and the degeneration of the RPE had to have an influence on the retinal function. He concluded that it would be rash to predict what these colloid changes would look like using ophthalmoscopy. Donders was convinced that the white flecks that he had seen several times in the eyes of old people suffering from 'senile amblyopia' (as loss of visual acuity in the elderly was called at that time) were not fatty metamorphoses but colloid degenerations [14]. An enviable clinical insight.

Albrecht Nagel was probably the first to publish on AMD, using both clinical and histological data from the same patient. He published on a 64-year-old woman with a dark-red net and partly confluent white flecks around both maculae who complained about marked 'amblyopia', increasing metamorphopsia, and a quivering image [40]. Fine brilliant specks were present, creating the impression of 'Krystalldrusen'. Nagel published again on this woman 
and some more cases with AMD [41]. The visual fields of these patients were normal and the eyes were never painful or inflamed. His first patient died at age 73 owing to an abdominal tumor; the eyes were enucleated $27 \mathrm{~h}$ post mortem and one was put in Müllers fixative. In the nonfixated eye, there were small, sparkling irregularities in the posterior pole on the inner side of the choroid. They contained hard grains with a diameter up to $0.5 \mathrm{~mm}$ that crunched under the tip of a knife. They were markedly similar to the whitish crystal-like drusen seen on ophthalmoscopy. Nagel concluded that the crystalline mass consisted of carbonic acid lime. On microscopy, lighter round flecks, surrounded by a black pigment ring were seen in the RPE. The flecks were created by thickenings of the elastic layer where the drusen, who were in the meantime dissolved in the fixative, had been and the outer retinal layer over them was markedly thinner. Nagel thought that this could explain the metamorphopsia and amblyopia the patient complained of.



Fig. 5 Large drusen (5) pressing against the retina (c) [14]. aa is choroid, b probably Bruch's membrane, c retina in which drusen protrude

\section{Terminology of AMD from 1855 onwards}

Table 2 lists the huge variety of terms that have been applied to what was probably AMD during the last 160 years. Only those that seem relevant, either because of their widespread use or the pathophysiologic concept they indicate, will be commented on. In 1874, Jonathan Hutchinson described a choroid, 'speckled with minute dots of yellowish white deposits' [36]. He considered the spots to be 'colloid excrescences of the lamina elastica' and wrote: 'There is no doubt that the disease is confined to the choroid in the first instance, whereas the great defect of sight which accompanies it points to implication of the retina secondarily'. He formulated three stages in the disease: 1 . Scattered yellow-white spots; 2 . Coalescence of these to patches with irregular borders; 3 . Hemorrhage at the yellow spot and absorption of the blood. Essentially, he thus had already described the present-day paradigm of the clinical course from drusen to late AMD. Nettleship mentioned in 1884 central guttate choroiditis, with a plate that clearly showed drusen, what we now would name early AMD (Fig. 6a) [42]. He also published in the same year on central senile areolar choroidal atrophy, probably now called dry late AMD (Fig. 6b) [43]. Soon afterwards, AMD was referred to as 'Hutchinsonian changes of the posterior pole of the eye' [44]. Wilhelm Goldzieher reported on four eyes of unspecified age with drusen-shaped flecks around the macula, and assumed that the changes were due to atheromatosis. Unlike Hutchinson he did not consider these changes a choroidal disorder, nor colloid excrescences of the vitreous membrane of the choroid, but compared them with cerebral leukomalacia caused by occlusions of the macular arterioles [44]. In subsequent years, diagnoses such as chorioretinitis [45], syphilis [46], or tumors [47-50] most likely were referring to AMD. a

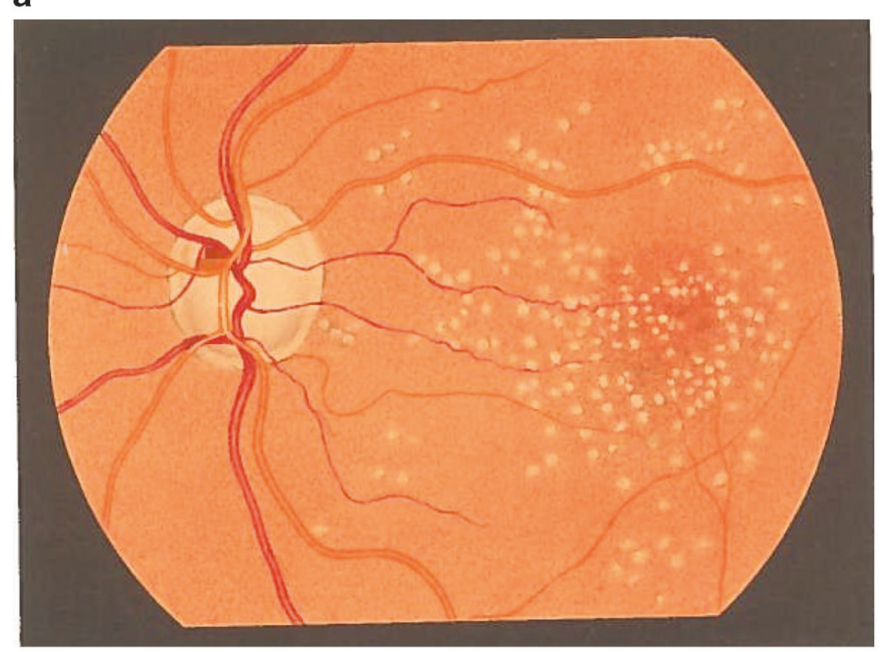

b

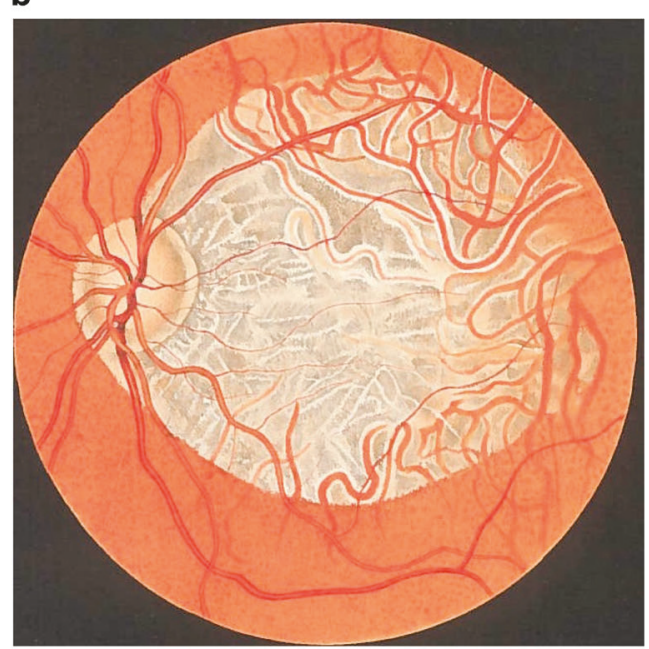

Fig. 6 (a) Central guttate choroiditis [42] (b) Central senile areolar choroidal atrophy [43] 
Table 2 Terminology of ageing macula disorder (AMD) from its very beginning ${ }^{\mathrm{a}}$

\begin{tabular}{llll}
\hline Year & Author & Original terminology & English (translation) \\
\hline 1855 & Donders [14] & $\begin{array}{l}\text { Entartung der Choriocapillaris und der } \\
\text { Pigmentschicht; Amblyopia senilis } \\
\text { Über chorioiditis areolaris und über Krystalle } \\
\text { im Augenhintergrunde }\end{array}$ & $\begin{array}{l}\text { Degeneration of the choriocapillaris and the pigment } \\
\text { layer; senile amblyopia }\end{array}$ \\
$\begin{array}{l}\text { On areolar choroiditis and on crystals in the ocular } \\
\text { background }\end{array}$ \\
1868 & Nagel [40] & Hutchinson [36] & $\begin{array}{l}\text { Symmetrical central choroido-retinal disease } \\
\text { occurring in senile persons; Tay's central guttate } \\
\text { choroiditis [49] }\end{array}$ \\
1875 & Nagel [68] & $\begin{array}{l}\text { Hochgradige Amblyopie, bedingt durch } \\
\text { glashäutige Wucherungen und krystallinische } \\
\text { Kalkablagerungen an der Innenfläche der }\end{array}$ & $\begin{array}{l}\text { Advanced amblyopia caused by proliferations on the } \\
\text { glass membrane and crystalline lime deposits on the } \\
\text { choroidal inner face }\end{array}$
\end{tabular}

1875 Pagenstecher [45]

1878 Michel [47]

1884 Nettleship [43]

1884 Nettleship [42]

1884 Masselon [27]

1885 Haab [51]

1887 Goldzieher [44]

1892 Caspar [68]

1893 Oeller [69]

1893 Fuchs [53]

1897 Walker [48]

1899 Silcock [46]

1899 Yarr [70]

1903 Jessop [49]

1903 Oeller [60]

1904 Batten [57]

1905 Possek [58]

1911 Lawford [72]

1912 Mosso [73]

1913 Heinrici [74]

1915 Axenfeld [15]

1915 Van der Hoeve [56]

1916 Hegner [75]

1919 Elschnig [50]

1920 Nöthen H [76]

1923 Coppez H [59]

1926 Junius, Kuhnt [61]

1926

Fuchs' Salzmann [22]
Kalkablagerungen an der Innenfläche der Aderhaut;

Chorioido-Retinitis in Regione Maculae Luteae;

Ueber Geschwülste des Uvealtractus

Infiltration vitré de la rétine

Erkrankungen der Macula Lutea; senile Maculaerkrankung;

Ueber die Hutchingsonse Veränderung des Augenhintergrundes

Senile Degeneration in der Gegend der macula lutea

Chorio-Retinitis centralis. Anastomosis arterio-venosa;

Retinitis circinata

Degeneratio maculae luteae disciformis;

Senile Maculaveränderung bei

Arteriosklerose;

Degenerazione disziforme della Macula;

Degeneratio circinata retinae (Ret. circinata Fuchs)

Retinitis externa exsudativa

Retinitis exsudativa externa

Retinitis exsudativa

Tumorähnliche Gewebswucherung in der Macula lutea;

Tumoren in der Maculagegend; Retinitis exsudativa haemorrhagica Coats;

Rétinite exsudative maculaire sénile

Die scheibenförmige Entartung der

Netzhautmitte (Degeneratio maculae luteae disciformis). Scheibenförmige Erkrankung der Netzhautmitte

Senile Makuladegeneration; zentrale senile Retinochoroiditis choroidal inner face

Chorioretinitis in the region of the macula lutea

On tumors of the uveal tract

Central senile areolar choroidal atrophy

Central guttate choroiditis

Glasslike retinal infiltration

Diseases of the macula lutea; Senile macular disease

On Hutchinsonian changes in the posterior pole of the eye

Senile degeneration in the region of the macula lutea

Central chorioretinitis. Arteriovenous anastomosis

Circinate retinitis

New growth in the macular region

Choroidal gumma

Central choroido-retinitis resembling an optic disc

Tumor in region of yellow spot

Disciform macular degeneration

Peculiar symmetrical swellings in the macular region

Senile macular change in arteriosclerosis

Subretinal new growth of doubtful nature

Disciform degeneration of the macula

Retinal circinate degeneration (Fuchs'circinate retinitis)

External exudative retinitis

External exudative retinitis

Exudative retinitis

Tumor-like tissue proliferation in the macula lutea

Tumors in the macular region; exudative hemorrhagic retinitis of Coats

Senile exudative macular retinitis

Disciform degeneration of the retinal center (Disciform macular degeneration). Disciform disease of the retinal center

Senile macular degeneration; central senile chorioretinitis 
Table 2 (continued)

\begin{tabular}{|c|c|c|c|}
\hline Year & Author & Original terminology & English (translation) \\
\hline 1937 & Verhoeff [2] & & Senile disciform degeneration of the macula \\
\hline 1944 & Laird [77] & & Senile macular degeneration \\
\hline 1959 & Maumenee [78] & & $\begin{array}{l}\text { Serous and hemorrhagic disciform detachment of the } \\
\text { macula }\end{array}$ \\
\hline 1966 & Duke-Elder [62] & & $\begin{array}{l}\text { Senile macular degeneration; Senile macular } \\
\text { chorioretinal degeneration; Senile macular } \\
\text { degeneration of Haab; Senile disciform degeneration } \\
\text { of the macula of Junius and Kuhnt }\end{array}$ \\
\hline 1967 & Gass [16] & & $\begin{array}{l}\text { Disciform detachment of the neuroepithelium; Senile } \\
\text { disciform macular detachment; Senile macular } \\
\text { degeneration; Senile macular choroidal degeneration }\end{array}$ \\
\hline 1969 & Straub [63] & Altersbedingte Maculadegeneration; & Age-determined macular degeneration \\
\hline 1977 & Wessing [79] & Exsudatieve senile Makulopathie & Exudative senile maculopathy \\
\hline 1985 & Folk [80] & & Aging macular degeneration \\
\hline 1987 & Sunness [64] & & Age-related macular degeneration \\
\hline 1992 & Klein [81] & & Age-related maculopathy \\
\hline 1996 & Holz [82] & Altersabhängige Makuladegeneration & Age-dependent macular degeneration \\
\hline 1997 & Pagliarini [83] & & Age-related macular disease \\
\hline 2004 & De Jong [83] & & Ageing macular disease \\
\hline 2006 & De Jong [4] & & Aging macula disorder \\
\hline 2014 & Camelo [65] & & Autoimmune macular disease \\
\hline
\end{tabular}

${ }^{a}$ Only the first time a certain concept was encountered is given here, unless for different [65] (historical) reasons

Although Edward Nettleship had already mentioned central senile areolar choroidal atrophy [43], Otto Haab was the first to report 1 year later in 1885 on 'Senile Makulaerkrankung', (senile macular disease) as a separate entity among the MDs, starting in the RPE (Fig. 1b) [20, 51, 52]. No other articles by Haab have come to light, explaining why he decided that senile MD was a separate entity. He concluded from analyzing over 50000 patient files that senile MD was about as frequent as traumatic MD and myopic macular affection. Senile MD was often bilateral and 'one should be wary of the outcome of a mature cataract operation when the fellow eye had this MD' [52]. It is striking that Haab explicitly stated that drusen, 'quite innocent changes in old persons', had nothing to do with senile MD (Fig. 1a) [20].

An article in 1893 by Fuchs on circinate retinitis, a circle of white flecks around the fovea [53], precipitated an avalanche of over 50 papers on this topic [54-56]. Circinate degeneration [55], or senile exudative retinitis were proposed as more precise terms [56]. A review on 61 out of 129 eyes with dMD having white spots, showed that $36 \%$ had circinate retinitis [2]. In 1904, 30 years after Hutchinson's paper, subretinal hemorrhages in AMD came again to the attention of researchers [57] and 1 year later atherosclerosis was suggested as a possible cause [58]. Also fibrous plaques in the macular area of old persons, in conjunction with punctate yellowish dots, followed by hemorrhages, were drawn and described as senile exudative macular retinitis [59].

In the legend which accompanies the image of the eye of a 79-year-old man from Johann Oeller's atlas (Fig. 7), the word 'disciform' appears to have been used for the first time [60]. The first image of disciform macular disease (dMD) was probably image number 6 in Hermann Pagenstecher's atlas called 'Choroido-Retinitis in the region of the macula lutea' $[45,61]$. The breakthrough in relation to 'disciform' MD, however, was the classic monograph by Paul Junius and his predecessor Hermann Kuhnt [61]. They described exhaustively 10 cases with an age range from 36 to 76 years, having a disciform process including five monocular ones, each with a good fellow eye. One case received a diagnosis 'disease' of the retinal center, one 'degeneration' of this center, and eight cases received both. Junius and Kuhnt concluded that circinate retinitis and disciform disease of the retinal center belonged to one large cluster of diseases. Only case I had increasing drusen-like spots along the inferior temporal venule and the term druse or colloid body, did not otherwise appear in any description of their cases. The word 'senile' appeared once in case II with 'senile vessel diseases'. The causes suggested for the disciform disorders varied from alcoholism and lues to hypertension and atherosclerosis. This monograph is valuable for the following three reasons: first, the excellent overview of the 


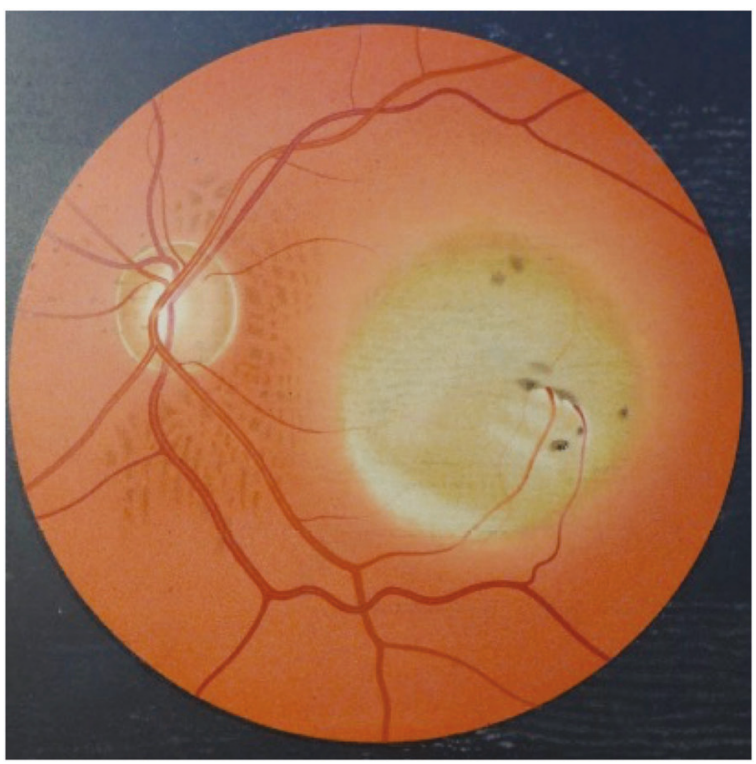

Fig. 7 Disciform macular degeneration. Male, 79 years old. Round center, over 2.5 diopter prominence [60]

past literature on dMD; second, the detailed color drawings; and, finally, it informed the wider public about dMD [61]. In the epilogue on page 132 was written: 'The expression disciform disease of the retinal center .. may appear somewhat bleak or dull.' Would this be the reason that they changed the title of their monograph from 'Erkrankung' (disease) to 'Entartung', (degeneration) in order to attract attention? [61] So what I always considered to be a monograph on end-stage AMD was actually a monograph on $\mathrm{dMD}$ caused by different retinal disorders, including a few cases with late AMD. Junius and Kuhnt could not help the fact that for many years their names were coupled to AMD. This was partly because Verhoeff [2] and later Duke-Elder [62] added to the original title of their monograph the word 'senile' or started a sub-chapter with: 'Senile disciform degeneration of the macula (of Junius and Kuhnt)'. The limited knowledge or interest in AMD around1965 may be apparent from Duke-Elder's System of Ophthalmology. It covered AMD in seven pages in the chapter 'Uveal manifestations of systemic diseases', under the sub-head 'Vascular sclerosis', using the terms 'Senile Macular Chorioretinal degeneration, Senile macular degeneration of Haab, (Haab named it senile macula disease!) or Senile Macular Degeneration' [62]. Drusen were dealt with in a few pages under the sub-category 'Secondary degenerations' [54].

\section{Ageing macula disorder}

Terminology showed fewer variations after 1965. Ophthalmologists gradually became aware that 'senile' MD is not a diagnosis patients are eager to hear, quite apart from its visual implications. 'Age-determined' as a substitute for 'senile' was first used in Germany [63] and later age-related appeared in the American literature [64]. In Table 2, one may see a gradual change after 1965 from senile maculopathy and age-related MD to age-related macular disease, ageing macula disease, ageing macula disorder, the latest term being 'autoimmune macular disorder' [65] (all abbreviated as $\mathrm{AMD}$ ).

On the eve that an article of mine [4] was due to go to the printer, I received a phone call from the editor-in-chief who wanted to change its title from Aging Macula Disorder into Age-related Macular Degeneration. We agreed to change the title but when placing my arguments for Aging Macula Disorder at the end of the article, some of their tenor was lost. In the interest of greater clarity, I will summarize my arguments here:

1. A good doctor should burden the patient with as little confusing or even alarming information as possible, especially when it has no therapeutic consequences. A few tiny drusen are not the same as late AMD. The Macular Disease Society in the UK, recently even dropped 'Disease' from its name, to the accompaniment of a huge round of applause by its members when this was announced at the annual meeting.

2. We know many types of MD, often in very specific age groups but 'age-related' does not adequately differentiate between MD in the newborn, infant [66], juvenile dMD [2], MD in the adult or in old persons.

3. Ageing macula simply signifies to me a macula in a person above a certain age, in the case of AMD commonly and arbitrarily set at age 50 [1].

4. The concept of degeneration in pathology is actually rather a vague one.

We achieved much since Donders, Nagel, Hutchinson, and Haab published their pioneering papers. I hope that this overview will place various historical concepts in proper perspective and stimulate young researchers to tie the loose ends still attached to AMD.

Acknowledgements I am greatly indebted to PG Breen BA HDE, JMBV de Jong MD PhD, JMJ Dony MD PhD, G Eisner MD PhD, BP Gloor MD PhD, J Jonas MD PhD, JEE Keunen MD $\mathrm{PhD}$, HR Koch MD PhD, PJ Koehler MD PhD, MJM Koomen MD DPharm, P Stoutenbeek MD, and Dr L Tey for critical reviewing of the text and/or help in obtaining or translating old manuscripts. To J.P.Wayenborgh for unconditional permission to use parts of a manuscript [84].

\section{Compliance with ethical standards}

Conflict of interest The authors declare that they have no conflict of interest. 
Open Access This article is licensed under a Creative Commons Attribution-NonCommercial-NoDerivatives 4.0 International License, which permits any non-commercial use, sharing, distribution and reproduction in any medium or format, as long as you give appropriate credit to the original author(s) and the source, and provide a link to the Creative Commons license. You do not have permission under this license to share adapted material derived from this article or parts of it. The images or other third party material in this article are included in the article's Creative Commons license, unless indicated otherwise in a credit line to the material. If material is not included in the article's Creative Commons license and your intended use is not permitted by statutory regulation or exceeds the permitted use, you will need to obtain permission directly from the copyright holder. To view a copy of this license, visit http://creativecommons.org/licenses/by-nc-nd/4.0/.

\section{References}

1. Bird AC, Bressler NM, Bressler SB, Chisholm IH, Coscas G, Davis MD et al. An international classification and grading system for age-related maculopathy and age-related macular degeneration. The International ARM Epidemiological Study Group. Surv Ophthalmol 1995;39:367-374.

2. Verhoeff FH, Grossman HP. The pathogenesis of disciform degeneration of the macula. Trans Am Ophthalmol Soc 1937;35:262-294.

3. Ryan SJ, Mittl RN, Maumenee AE. The disciform response:an historical perspective. Albrecht Von Graefes Arch Klin Exp Ophthalmol 1980;215:1-20.

4. De Jong. PTVM. Age-related macular degeneration. Mechanisms of disease. N Engl J Med 2006;355:1474-1485.

5. Duke-Elder S, Wybar KC. The anatomy of the visual system II. The vascular tunic In:The anatomy of the visual system. Kimpton: London, 1961.

6. Wolfrum M. Beiträge zur Anatomie und Histologie der Aderhaut beim Menschen und bei höheren Wirbeltieren. Contributions to the anatomy and histology of the choroid in humans and higher vertebrates. Graefes Arch Clin Exp Ophthalmol 1908;67:307-359.

7. Ramrattan RS, van der Schaft TL, Mooy CM, de Bruijn WC, Mulder PG, de Jong PTVM. Morphometric analysis of Bruch's membrane, the choriocapillaris, and the choroid in aging. Invest Ophthalmol Vis Sci 1994;35:2857-2864.

8. Bruch C. Untersuchungen zur Kenntnis des körnigen Pigments der Wirbelthiere in physiologischer und pathologischer Hinsicht Investigations of the granular pigments of vertebrates in a physiologic and pathologic sense. Zürich: Mayer u Zeller, 1844.

9. Eschricht DF. Beobachtungen an dem Seehundsauge. Observations on the seal eye. Archiv für Anatomie. Physiologie und wissenschaftliche Medicin 1838;575-599.

10. Müller H. Anatomische Beiträge zur Ophthalmologie. Anatomical contributions to ophthalmology. Archiv für Ophthalmologie $1856 ; 1-100$.

11. Querques G, Georges A, Ben MN, Sterkers M, Souied EH. Appearance of regressing drusen on optical coherence tomography in age-related macular degeneration. Ophthalmology 2014;121:173-179.

12. Mondini C. De oculi pigmento On the ocular pigment. De Bononiensi scientiarum et artium instituto atque academia commentarii 1791;7:29-32.

13. De Jong PTVM. A historical analysis of the quest for the origings of aging maula disorder, the tissues involved, and its terminology. Ophthalmol Eye Dis 2016;8:5-14.

14. Donders FC. Beiträge zur pathologischen Anatomie des Auges. Contributions to the pathologic anatomy of the eye. Archiv für Ophthalmologie 1855;106-118.
15. Axenfeld T. Retinitis externa exsudativa mit Knochenbildung im Sehfähigen Auge. External exudative retinitis with bone formation in a seeing eye. Graefes Arch Clin Exp Ophthalmol 1915;452-470.

16. Gass JDM. Pathogenesis of disciform detachment of the neuroepithelium, III. Senile disciform macular degeneration. Am J Ophth 1967;63:617/45-644.

17. Lerche W. Elektronenmikroskopische Beobachtungen über altersbedingte Veränderungen an der Bruchschen Membran des Menschen. Electron microscopic onbservations on age-related changes in human Bruch's membrane. Anat Gesell Verh 1964;123-132.

18. Sarks SH. The fellow eye in senile disciform degeneration. Trans Aust Coll Ophthalmol 1970;2:77-82.

19. Sarks SH. Ageing and degeneration in the macular region:a clinico-pathological study. Br J Ophthalmol 1976;60:324-341.

20. Haab O. Atlas und Grundriss der Ophthalmoskopie und ophthalmoskopischen Diagnostik. Atlas and outline of ophthalmoscopy and ophthalmoscopic diagnostics. Lehmann: München, 1895.

21. Wedl C. Grundzüge der pathologischen Histologie. Outlines of pathologic histology. Wien: Gerold, 1854.

22. Salzmann M. Fuchs Lehrbuch der Augenheilkunde. Fuchs' textbook of ophthamology. 15 edn. Deuticke: Leipzig, 1926.

23. Jäger von Jaxtthal E. Ophthalmoskopischer Hand-Atlas. Ophthalmoscopic hand atlas. k.k.Hof- und Staatsdruckerei: Wien: Gerold, 1869;236.

24. Mimoun G, Soubrane G, Coscas G. Les drusen maculaires. Macular drusen. J Fr Ophthalmol 1990;13:19.

25. Rudnew A. Ueber die Enstehung der sogenannten Glaskörper der Choroides des menschlichen Auges und über das Wesen der hyalinen Degeneration der Gefässe derselben. On the origin of the so-called vitreous bodies of the choroid in the human eye and on the essence of the hyaline degeneration of its vessels. Virchow Archiv 1871;455-465.

26. Rossberger S, Ach T, Best G, Cremer C, Heintzmann R, Dithmar $\mathrm{S}$. High-resolution imaging of autofluorescent particles within drusen using structured illumination microscopy. Br J Ophthalmol 2013;97:518-523.

27. Masselon JMémoires d'ophtalmoscopie. Infiltration vitreuse de la rétine et de la papille. Ophthalmoscopic memoirs. Glasslike infiltrations of the retina and the disc. O. Doin: Paris, 1884.

28. Hirschberg J. Die Anatomie des Auges bei den alten Griechen. The anatomy of the eye with the ancient Greeks. Engelmann: Leipzig, 1899.

29. Platter F. De corporis humani structura et usu On the structure and function of the human body. Basel: Froben, J, 1583.

30. Leeuwenhoek A. Letter 13. Phil Trans R Soc 1674;10:378-380.

31. Treviranus GR.Resultate neuer Untersuchungen über die Theorie des Sehens und über den innern Bau der Netzhaut des Auges. Results of new research on the theory of vision and on the internal structure of the retina of the eye. Bremen: Heyse, J.G, 1837.

32. Bidder F. Zur Anatomie der Retina, insbesondene zur Würdigung der stabförmigen Körper in derselben. On the retinal anatomy, especially with respect to its rod-shaped bodies. Archiv für Anatomie, Physiologie und wissenschaftliche Medicin 1839;263-385.

33. Kölliker A. Zur Anatomie und Physiologie der Retina. On the anatomy and physiology of the retina. Verhandlungen der Physikalisch-Medizinischen Gesellschaft zu Würzburg 1852;316-336.

34. Berson DM, Dunn FA, Takao M. Phototransduction by retinal ganglion cells that set the circadian clock. Science 2002;295:1070-1073.

35. Buzzi F. Nuove sperienze fatte sull'occhio umano. New Experiments done on the human eye. Milano: Mareli, 1782;87-95. 
36. Hutchinson J. Symmetrical central choroido-retinal disease occurring in senile persons. The Royal London Ophthalmic Hospital records and journal of ophthalmic medicine and surgery 1874;231-244.

37. Kliffen M, Sharma HS, Mooy CM, Kerkvliet S, De Jong PTVM. Incresed expression of angiogenic growth factors in age-realed maculopathy. Br J Ophthalmol 1997;81:154-162.

38. Helmholtz H. Beschreibung eines AUGEN-SPIEGELS zur Untersuchung der Netzhaut im lebenden Auge. Description of an ophthalmoscope for examination of the retina in the living eye Berlin. A. Förstner'sche Verlagsbuchhandlung, 1851.

39. Duke-Elder S, Dobree JJ. Diseases of the retina. The beginnings of ophthalmoscopy. Kimpton: London, 1967.

40. Nagel A. Ueber Chorioiditis areolaris und über Krystalle im Augenhintergrund. On areolar choroiditis and crystalls in the eye fundus. Klin Monbl Augenheilk 1868;4:417-420.

41. Nagel A. Hochgradige Amblyopie, bedingt durch glashäutige Wucherungen und krystallinische Kalkablagerungen an der Innenfläche der Aderhaut. Severe amblyopia due to growths of the glass membrane and crystalline calcium deposits on the inner surface of the choroid. Kl Monatsbl Augenh 1875;13:338-351.

42. Nettleship E. Central guttate choroiditis without defect of sight; premature presbyopia. Trans Ophth Soc UK 1884;4:2.

43. Nettleship E. Central senile areolar choroidal atrophy. Trans Ophth Soc UK 1884;165-166.

44. Goldzieher W. Die Hutchinson'sche Veränderung des Augenhintergrundes. The Hutchinsonian change in the eye fundus. Wiener Medizinische Wochenschrift 1887;37:861-865.

45. Pagenstecher H, Gent C. Atlas der pathologischen Anatomie des Augapfels. Atlas of the pathologic anatomy of the eye ball. Kreidel, C.W: Wiesbaden, 1875.

46. Silcock AQ. Choroidal gumma. Trans Ophth Soc UK 1899;69-71.

47. Michel J. Ueber Geschwülste des Uvealtractus. On tumours of the uveal tract. Graefes Arch Clin Exp Ophthalmol $1878 ; 131-147$.

48. Walker $\mathrm{CH}$. A case of? new growth in the macular region. Trans Ophth Soc UK 1897;64-65.

49. Jessop WH. Tumour in region of yellow spot. Trans Ophth Soc UK 1903;384-386.

50. Elschnig A. Tumorähnliche Gewebswucherung in der Macula lutea. Tumour-like tissue proliferation in the macula lutea. Klin Mbl Augenh 1919;62:145-154.

51. Haab O. Erkrankungen der Macula Lutea. Diseases of the macula lutea. Centralblatt für praktische Augenheilkunde 1885;383-384.

52. Haab O. Ueber die Erkrankung der Macula lutea. On the illness of the macula lutea. Proceedings of the VIIth international ophthalmologic congress, Heidelberg, 1888.

53. Fuchs E. Retinitis circinata. Circinate retinitis. Graefes Arch Clin Exp Ophthalmol 1893;229-279.

54. Duke-Elder S, Dobree JH. System of ophthalmology. Diseases of the retina. Degenerations and dystrophies. London: Kimpton, H., 1967.

55. Goldzieher W. Die Hutchinson'sche Veränderung des Augenhintergrundes (Retinitis circinata Fuchs). The Hutchinsonian change in the eye fundus (Fuchs' circinate retinitis). Archiv f Augenheilkunde 1897;34:112-134.

56. Van der Hoeve J. Retinitis exsudativa. Exudative retinitis. Ned Tijdschr Geneeskd 1915;59:1637-1640.

57. Batten R. Peculiar symmetrical swellings in the macular region, apparently due to subretinal heamorrhage. Trans Ophth Soc UK 1904;24:127.

58. Possek R. Ueber senile Maculaveränderung bei Arteriosclerose. On senile macular change in arteriosclerosis. Z Augenheilkunde 1905;771-779.
59. Coppez H, Danis M. Rétinite exsudative maculaire sénile. Senile exudative macular retinitis. Archives d'Ophtalmologie 1923;40:129-154.

60. Oeller J. Atlas seltener opthalmoskopischer Befunde. Atlas of rare ophthalmoscopic findings. Bergmann, J.F: Wiesbaden, 1904.

61. Junius P, Kuhnt H. Die scheibenförmige Entartung der Netzhautmitte. Degeneratio maculae luteae disciformis. The disciform degeneration of the central retina. Disciform macula lutea degeneration. Karger, S.: Berlin, 1926.

62. Duke-Elder S, Perkins ES. Uveal manifestations of systemic diseases. Vascular diseases. Kimpton: London, 1966.

63. Straub W. Altersbedingte maculadegeneration. Age-determined macular degeneration. Deutsche medizinische Wochenschrift 1969;94:1385-1386.

64. Sunness JS. Age-related macular degeneration: how science is improving clinical care. Interview by Marc E. Weksler. Geriatrics 1998;53:70-80.

65. Camelo S. Potential sources and roles of adaptive immunity in age-related macular degeneration: shall we rename amd into autoimmune macular disease?Autoimmune Dis 2014;2014:532487.

66. Knapp A. Retinal degeneration in macular region without cerebral symptoms. Trans Am Ophthalmol Soc 1928;26:155-161.

67. van Trigt AC. De speculo oculi ejusque usu. On the ophthalmoscope and its use. Utrecht: Kemink, 1853.

68. Caspar L. Ein Fall von seniler Degeneration in der Gegend der macula lutea. A case of senile degeneration in the region of the macula lutea. Klin Monatsbl Augenheilk 1892;30:284-287.

69. Oeller J. Atlas der Ophthalmoskopie. Atlas of ophthalmoscopy. Bergmann, J.F: Wiesbaden, 1896.

70. Yarr MT. Central choroido-retinitis, resembling an optic disc, in a patient suffering from glycosuria. Trans Ophth Soc UK $1899 ; 68-69$.

71. Lawford JB. A case of subretinal new growth of doubtful nature. Trans Ophth Soc UK 1911;31:257-260.

72. Mosso G. Degenerazione disciforme della macula. Anastomosi arterio-venosa. Disciform degeneration of the macula. Arterio-venous anastomoses. Annali di Ottalmologia 1912;41:325-337.

73. Heinricy O, Harms C. Klinische Beiträge zur Degeneratio circinata retinae [Retinitis circinata (Fuchs)] mit besonderer Berücksichtigung der atypischen Formen des Krankheitsbildes. Clinical contributions to circinate degeneration of the retina [Fuchs'circinate retinitis] with special emphasis on the atypical forms of the clinical picture. Graefes Arch Clin Exp Ophthalmol 1913;86:514-548

74. Hegner CA. Retinitis exsudativa bei Lymphogranulomatosis. Exudative retinitis in lymphogranulomatosis. Klin Monbl Augenh 1916;57:27-48.

75. Nöthen H. On simulation of tumours in the macular area by haemorrhagic exudative retinitis of Coats. Ueber Vortäuschung von Tumoren in der Maculagegend durch Retinitis exsudativa haemorrhagica Coats. Trapp, H: Bonn, 1920.

76. Laird RG. Iodide therapy for senile macular degeneration. Trans Am Ophthalmol Soc 1944;42:480-494.

77. Maumenee AE. Serous and hemorrhagic disciform detachment of the macula. Tr Pacif Coast Oto-ophth Soc 1959;40:139-169.

78. Wessing A. Die exsudative senile Makulopathie, klinisches Bild, Pathogenese, prognose und Therapie. The exudative senile maculopathy, clinical picture, pathogenesis, prognosis and therapy. Klin Mbl Augenheilk 1977;171:371-384.

79. Folk JC. Aging macular degeneration. Clinical features of treatable disease. Ophthalmology 1985;92:594-602.

80. Klein R, Meuer SM, Moss SE, Klein BEK. Detection of drusen and early signs of age-related maculopathy using a nonmydriatic 
camera and a standard fundus camera. Ophthalmology 1992;99:1686-1692.

81. Holz FG, Wolfensberger TI, Piguet B, Minassian D, Bird AC. Makuläre drusen. Macular drusen. Ophthalmologe 1994;91:735-740.

82. Pagliarini S, Moramarco A, Wormald RP, Piguet B, Carresi C, Balacco-Gabrieli $\mathrm{C}$ et al. Age-related macular disease in rural southern Italy. Arch Ophthalmol 1997;115:616-622.
83. De Jong PTVM, Lubsen J. The standard gamble between cataract extraction and AMD. Graefes Arch Clin Exp Ophthalmol 2004;242:103-105.

84. De Jong PTVM. Elusive ageing macula disorder (AMD). Hist Ophth Int 2015;1:1303-152. 